\title{
OCENA MOŻLIWOŚCI ZASTOSOWANIA GEODEZYJNYCH TECHNIK POMIARÓW DO WYZNACZANIA DEFORMACJI GÓROTWORU NA TERENIE KOPALNI SOLI „KLODAWA”
}

\begin{abstract}
Jednym z aspektów funkcjonowania głębinowej kopalni soli jest osiadanie powierzchni terenu i części górotworu, znajdującego się ponad wyrobiskami. Proces ten powinien być stale monitorowany, m.in. poprzez pomiary geodezyjne. Celem pracy jest pokazanie możliwości zastosowania geodezyjnych technik do badania zjawiska deformacji górotworu w obszarze eksploatacji złoża soli kamiennej w Kopalni Soli „Kłodawa”. Pierwszym etapem podjętych prac była stabilizacja wielofunkcyjnej sieci obserwacyjnej w wyrobiskach najwyższych poziomów kopalni. Następnie sieć została pomierzona z zastosowaniem kilku technik pomiarów geodezyjnych. Finalnym efektem pracy jest analiza otrzymanych wyników pomiarów w odniesieniu do danych archiwalnych. Wyniki tej analizy mają posłużyć do określenia kierunków działań zmierzających do zapewnienia dalszej, bezpiecznej i efektywnej eksploatacji wysadu kłodawskiego.
\end{abstract}

Słowa kluczowe: przemieszczenia, konwergencja, stabilizacja reperów, niwelacja

\section{Wstęp}

W celu zapewnienia bezpiecznego funkcjonowania głębinowej kopalni soli kamiennej (m.in. Kopalni Soli „Kłodawa”) niezbędne staje się prowadzenie stałej obserwacji oraz kontroli zjawisk towarzyszących eksploatacji. Jednym z tych zjawisk jest proces osiadania powierzchni terenu i części górotworu znajdującego się nad wyrobiskami kopalnianymi. Proces ten powinien być stale monitorowany przez odpowiednie, powołane do tego służby miernicze (geodezyjne) i geologiczne, których zadaniem jest wykonywanie cyklicznych obserwacji specjalnych sieci pomiarowych. Nadrzędnym celem tych działań ma być zapewnienie należytego bezpieczeństwa załogi kopalni oraz mieszkańców terenów objętych zasięgiem

${ }^{1}$ Michał Bieniasz, Uniwersytet Rolniczy w Krakowie; Wydział Inżynierii Środowiska i Geodezji; Katedra Geodezji; michalbieniasz@interia.pl

2 Autor do korespondencji/ corresponding author: Tadeusz Gargula, Uniwersytet Rolniczy w Krakowie; Wydział Inżynierii Środowiska i Geodezji; Katedra Geodezji; tadeusz.gargula@urk.edu.pl 
wpływów eksploatacyjnych. Innym ważnym aspektem jest zagwarantowanie jak najdłuższej i efektywnej eksploatacji złoża.

W niniejszej pracy wykorzystane zostały m.in. doświadczenia autora [2], zdobyte dzięki współpracy z firmą „Chemkop” [15], prowadzącą pomiary w podziemnych wyrobiskach Kopalni Soli „Kłodawa”. Prace przygotowawcze polegały na zastabilizowaniu specjalnej sieci pomiarowej, służącej do badania deformacji stropowej półki ochronnej nad filarowo - komorowym górotworem pól eksploatacyjnych kopalni. Do badania deformacji wykorzystuje się m.in. geodezyjne techniki pomiarowe (pomiary niwelacyjne i długościowe). Założona sieć obserwacyjna powinna mieć charakter kompleksowy, pozwalający rejestrować oraz monitorować wszelkie deformacje wnętrza górotworu nad kilkoma polami eksploatacji w kłodawskiej kopalni. Przedmiotem prowadzonych pomiarów będą przemieszczenia pionowe wnętrza górotworu w rejonie spągu półki ochronnej, przemieszczenia poziome na wydzielonych liniach pomiarowych oraz konwergencja, czyli zaciskanie wyrobisk komorowych i chodnikowych.

W niniejszej pracy dość często stosowana jest fachowa terminologia, ściśle związana $\mathrm{z}$ funkcjonowaniem kopalni soli kamiennej, dlatego poniżej podano krótkie definicje tych zwrotów, które nie są oddzielnie wyjaśniane tekście:

- Stropowa pótka ochronna: calizna solna pozostawiona ponad wyrobiskami najwyższych poziomów eksploatacyjnych w celu ograniczenia niekorzystnych wpływów pochodzących od eksploatacji na nadległy górotwór i powierzchnię;

- Filarowo-komorowy system eksploatacji: sposób eksploatacji złóż soli (w Polsce stosowany jedynie w kopalni w Kłodawie), polegający na tym, że sól wydobywana jest z szeregu równoległych do siebie komór oddzielonych odpowiedniej szerokości filarami podporowymi;

- Pola eksploatacyjne kopalni: rejony wydobycia soli, wydzielone ze względu na budowę geologiczną złoża;

- Spag pótki ochronnej: najniżej położny rejon półki (najwyższy poziom wydobycia);

- Pótki i filary międzykomorowe: calizny skalne (solne), czyli pozostawione fragmenty złoża oddzielające wyrobiska eksploatacyjne na danym poziomie (filary) lub pomiędzy poziomami wydobywczymi (półki);

- Wysad kłodawski: złoże soli (o długości ok. 26 km i szerokości ok. 2 km), w centrum którego zlokalizowana jest Kopalnia Soli Kłodawa;

- Okres cechsztyński: okres, w którym powstawały złoża soli na obecnych ziemiach polskich; miało to miejsce około $265 \mathrm{mln}$ lat temu (późny perm);

- Filar brzeżny: calizna solna pozostawiona pomiędzy granicą wysadu (złoża solnego) a najbliższymi wyrobiskami górniczymi;

- Ociosy: ściany boczne wyrobisk (chodników, komór);

- Odspojenia ociosów i stropów: wynik działania naturalnych sił zaciskających przestrzeń wykonanego wyrobiska, tj. naruszonego górotworu; 
- Lutnie metalowe: wieloelementowe rury służące do lokalnej wentylacji wyrobisk kopalnianych;

- Calizna pótki ochronnej: fragment nienaruszonego robotami górniczymi górotworu pozostawionego nad wyrobiskami;

- Przekop: główny chodnik w kopalni.

\section{Charakterystyka obiektu pomiaru}

Obecnie Kopalnia Soli „Kłodawa” jest największym w kraju producentem soli kamiennej. Wydobycie prowadzi się tutaj tradycyjną metodą górniczą, która pozwala na zachowanie wszystkich walorów kłodawskiej soli. Solne produkty spożywcze uzyskuje się w zakładzie na drodze przeróbki mechanicznej bez dodawania jakichkolwiek substancji chemicznych. Stosuje się komorowy system eksploatacji, z pozostawieniem półek i filarów międzykomorowych. W pierwszych latach eksploatacji (lata 50-te XX wieku) wydobycie prowadzono na poziomach od 450 do $600 \mathrm{~m}$; w chwili obecnej prace górnicze prowadzone są już nawet na poziomie $750 \mathrm{~m}$. Zasoby znajdujące się w wysadzie do tej głębokości mogłyby zapewnić ekonomiczny byt kopalni na następne dziesiątki lat, gdyby nie wiele zagrożeń, jakie niesie ze sobą prowadzenie takiej eksploatacji. Są to m.in. zagrożenia metanowe, zagrożenia tąpaniami oraz jedno z największych zagrożeń dotyczących kopalni soli - zagrożenie wodne [16].

W charakterystyce kłodawskiej kopalni warto również wspomnieć o otwartej w 2004 roku najgłębszej na świecie podziemnej trasie turystycznej. W programie zwiedzania przewidziano informację o historii powstania złóż kłodawskich pochodzących z okresu cechsztyńskiego. Następnie proponowany jest zjazd windą na poziom $600 \mathrm{~m}$ pod powierzchnię ziemi i przejście wyrobiskami korytarzowymi do solnej groty, gdzie znajduje się kaplica św. Kingi z jej solną rzeźbą. W trakcie zwiedzania istnieje możliwość podziwiania wyeksploatowanych komór, chodników i maszyn, używanych w podziemnym górnictwie solnym w przeszłości i współcześnie. Do niezwykle ważnych informacji dotyczących prezentowanej kopalni należy fakt, że w 2007 roku najstarsza jej część została wpisana do rejestru zabytków. Ciekawostką może być wydarzenie z 20 kwietnia 2007 roku, kiedy to Filharmonia Kaliska zagrała w podziemiach kłodawskiej kopalni koncert („Cztery pory roku” A. Vivaldiego) na głębokości 600 metrów, ustanawiając w ten sposób rekord Guinnesa [17].

$\mathrm{Na}$ terenach dzisiejszej kopalni jeszcze przed II wojną światową zostały wykonane badania grawimetryczne, które wykazały zalegające pod ziemią ogromne złoże soli kamiennej oraz soli magnezowo - potasowych. Badania wykonał profesor Edward Walery Janczewski, geolog i geofizyk, wykładowca Akademii Górniczo - Hutniczej w Krakowie. Odkrył on istnienie ogromnej struktury solnej o długości ok. $26 \mathrm{~km}$ oraz szerokości ok. $2 \mathrm{~km}$ [17], co potwierdziły już pierwsze wiercenia wykonane w latach $1945-1950$. 


\section{Analiza możliwości oraz warunków prowadzenia pomiarów geodezyjnych na terenie kopalni soli}

Każda działalność człowieka naruszająca górotwór powoduje szereg zmian i deformacji zauważalnych zarówno wewnątrz górotworu, jak i na jego powierzchni oraz obiektach leżących w strefie wpływów wspomnianej aktywności. Składa się na to cały szereg procesów podlegających naturalnym prawom i zmierzającym do uzyskania równowagi wtórnej. Przed wystąpieniem gwałtownych rozprężeń górotworu pojawiają się z reguły okoliczności, które pozwalają przewidzieć wystąpienie niepożądanych skutków na powierzchni ziemi oraz w jej wnętrzu [9], [11]. Każdy górotwór (ogół skał tworzących skorupę ziemską) posiada inne właściwości geomechaniczne. Aby bezpiecznie prowadzić działalność górniczą należy jak najlepiej poznać jego właściwości, co wiąże się z ustaleniem zagrożeń, jakie niesie ze sobą eksploatacja górnicza danego złoża.

W nienaruszonym górotworze, pod ciężarem zalegających warstw powstają w skałach naprężenia o wartości proporcjonalnej do głębokości. Działalność górnicza powoduje powstanie dodatkowych naprężeń górotworu i równoczesne zaburzenie jego równowagi. Powstają wtedy siły działające w kierunku utworzonej w górotworze pustki, a noszą one ogólną nazwę „ciśnienia górotworu”. Ciśnienie to powoduje między innymi pękanie i odspajanie skał na powierzchniach wyrobiska i może prowadzić do jego uszkodzenia, a w skrajnych przypadkach do zniszczenia. Oddzielną dyscypliną naukową, która zajmuje się skutkami wywołanymi przez ciśnienie górotworu w wyrobiskach kopalnianych, jest mechanika górotwo$\mathrm{ru}[4]$.

Najistotniejszym zagrożeniem w kopalniach soli jest zagrożenie wodne, czyli możliwość wdarcia się do kopalni wód z otaczającego górotworu. Prowadzić mogą do tego wszelkie deformacje górotworu wpływające na powstanie lub udrożnienie kontaktu wód $\mathrm{z}$ otoczenia wysadu z podziemnymi wyrobiskami. $\mathrm{Z}$ tego właśnie względu ruch górotworu oraz powierzchni terenu należy stale monitorować wszelkimi dostępnymi sposobami. Istnieje szereg czynników, które mają wpływ na deformację górotworu w kopalniach soli, m.in.: wymiary komór, filarów i półek, rozpiętość kopalni w pionie i poziomie, sposób i tempo eksploatacji oraz okres istnienia pustek [6]. Jedną z metod minimalizowania ryzyka występowania zagrożeń $\mathrm{w}$ kopalniach soli jest pozostawianie $\mathrm{w}$ nich nad górnym poziomem 200 - 300-metrowej półki ochronnej i 50-metrowego filara brzeżnego.

Przykłady historycznych katastrof w dwóch nieczynnych już polskich kopalniach soli - w Wapnie (k. Wągrowca) i Inowrocławiu $[5,6,7]$, będących wynikiem długotrwałej i nieprzemyślanej eksploatacji oraz zignorowania naturalnych zagrożeń wodnych - pokazują jak wiele pracy powinno się włożyć w obsługę geologiczno - mierniczą (geodezyjną). Cykliczne badania i pomiary należy prowadzić przed rozpoczęciem eksploatacji, w trakcie jej trwania oraz po jej zakończeniu. Nadrzędnym celem jest dążenie do uniknięcia zagrożeń oraz zminimalizowania ich skutków. 
Oprócz przemieszczeń pionowych i poziomych górotworu, w kopalniach występuje zjawisko konwergencji. W miernictwie górniczym termin ten oznacza proces zaciskania (zbiegania się) ociosów oraz spągu ze stropem wyrobiska. Zjawisko to spowodowane jest działaniem siły ciężkości, a w solnym górotworze decydujący wpływ na to mają takie parametry, jak wilgotność i temperatura. O jego rozwoju bądź nasileniu w głównej mierze decydują właściwości reologiczne skał - w tym wypadku soli (reologia to dziedzina nauki opisująca zachowanie ciał poddanych naprężeniom). Z pozostałych czynników, ważnych z punktu widzenia działania konwergencji, wymienić należy: głębokość wyrobiska, jego wymiary, pierwotny stan naprężenia oraz sposób prowadzenia robót górniczych. Zjawisko zaciskania $\mathrm{w}$ górotworze solnym przebiega $\mathrm{w}$ długim okresie czasu, jednak w początkowej fazie po utworzeniu pustki ma ono przebieg gwałtowny [8]. Przejawem występowania zjawiska konwergencji mogą być charakterystyczne odkształcenia krzywizn konturu wyrobiska, połamane i zmiażdżone belki obudowy chodników, sprasowany materiał skalny $\mathrm{z}$ obwałów lub wybrzuszone ścianki zamykające wejścia do komór (Rys. 1, 2).

Rys. 1. Efekt zaciskania pionowego pochylni w rejonie wykonywania pomiarów

Fig. 1. Clamping vertical effect of a ramp in the area of measurement

Rys. 2. Przykład poziomego zaciskania ociosów wyrobiska

Fig. 2. Example of horizontal clamping of the excavated hollows
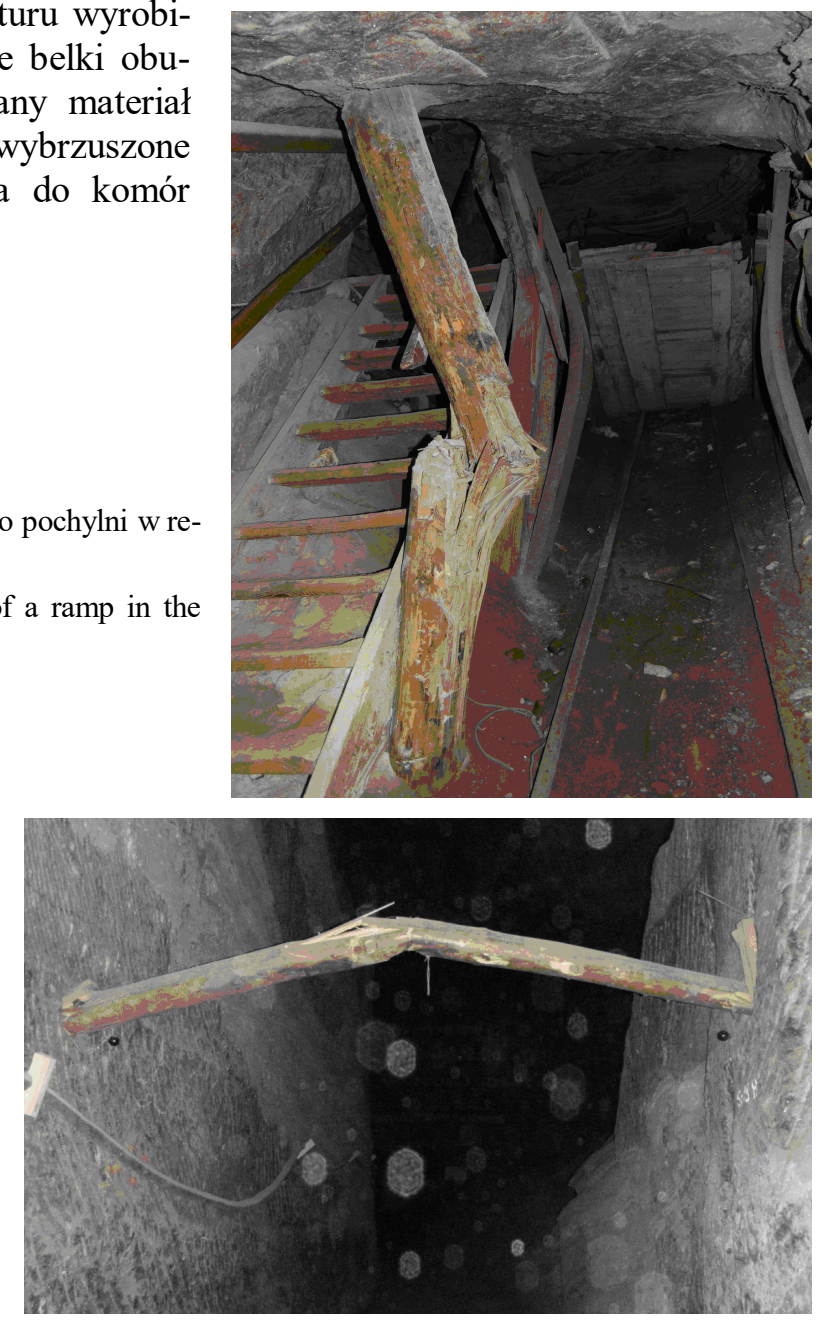
Zasady funkcjonowania zakładów górniczych reguluje wiele aktów prawnych, w tym te dotyczące sporządzania dokumentacji mierniczo - geologicznej. Nadrzędnym aktem jest Ustawa z dnia 9 czerwca 2011 r. - Prawo geologiczne i górnicze [12], która określa m.in. zasady i warunki podejmowania, wykonywania oraz zakończenia działalności w zakresie wydobywania kopalin ze złóż. Ustawa podaje również wymagania w zakresie ochrony złóż, wód podziemnych oraz innych elementów środowiska naturalnego związanych z wykonywaniem prac górniczych. Aktem wykonawczym do tej ustawy jest Rozporzadzenie Ministra Środowiska $z$ dnia 22 grudnia 2011 roku w sprawie dokumentacji mierniczo - geologicznej [10]. Rozporządzenie to zawiera m.in. wiele szczegółów z zakresu tworzenia i edycji map wyrobisk górniczych, map sytuacyjno - wysokościowych w granicach terenu górniczego, profili otworów wiertniczych oraz przekrojów geologicznych. $Z$ punktu widzenia służb geodezyjnych najważniejszym elementem tego rozporządzenia jest Załącznik nr $1 \mathrm{pt}$. Szczególowe wymagania dotyczace wykonywania prac geodezyjnych $i$ geologicznych $w$ celu sporzadzenia, aktualizacji i uzupetnienia dokumentacji mierniczo - geologicznej. Kluczową

częścią Załącznika jest część III, traktująca o osnowach geodezyjnych na terenach kopalń, ich podziale, klasach dokładnościowych oraz metodach stabilizacji punktów. Znajduje się tam wiele zaleceń oraz informacji nt. pomiarów długości boków, kątów, różnic wysokości. Zawarte w Załączniku wytyczne i wskazówki mogą być niezwykle cenne, zarówno $\mathrm{w}$ trakcie przeprowadzania wspomnianych pomiarów w wyrobiskach kopalnianych, jak i podczas prac kameralnych, mających na celu właściwą analizę i interpretację uzyskanych danych pomiarowych.

Przeprowadzenie właściwego pomiaru punktów sieci w podziemnej kopalni soli musi być poprzedzone pracami projektowymi odnośnie odpowiedniego rozmieszczenia punktów pomiarowych, tak aby możliwe było zaobserwowanie jak największej liczby zjawisk zachodzących wewnątrz górotworu. Prace projektowe wiążą się z dokładnym rozpoznaniem wyrobisk, komór i chodników, w których będą zastabilizowane punkty. Na tym etapie należy wziąć pod uwagę następujące, możliwe utrudnienia:

- duże prędkości przepływu powietrza w wyrobiskach położonych najbliżej szybów wentylacyjnych (brak możliwości spoziomowania niwelatora, niestabilność łat niwelacyjnych);

- obwały i odspojenia ociosów i stropów (aż do stanu zwałowego) w niektórych przekopach;

- wypełnienie przekroju przekopów lutniami metalowymi lub innymi pozostałościami po działalności górniczej (brak możliwości instalacji znaków).

Pomiary niwelacyjne $\mathrm{w}$ podziemnych kopalniach sprawiają znacznie więcej trudności niż na powierzchni ziemi. Wiąże się to $\mathrm{w}$ głównej mierze $\mathrm{z}$ niedostatecznym oświetleniem oraz szybkim przepływem powietrza w rejonach szybów i tam wentylacyjnych.

Pierwsze pomiary niwelacyjne powierzchni terenu ponad kopalnią w Kłodawie pochodzą z 1952 roku (okres budowy kopalni) i odnoszą się do szczątkowej 
sieci reperów nad centralnym rejonem pola nr 1 (Rys. 3). Wyniki pozwalają oszacować sumaryczne przemieszczenia pionowe tego rejonu od początku istnienia kopalni. Natomiast pierwsze pomiary niwelacyjne wnętrza górotworu rozpoczęto

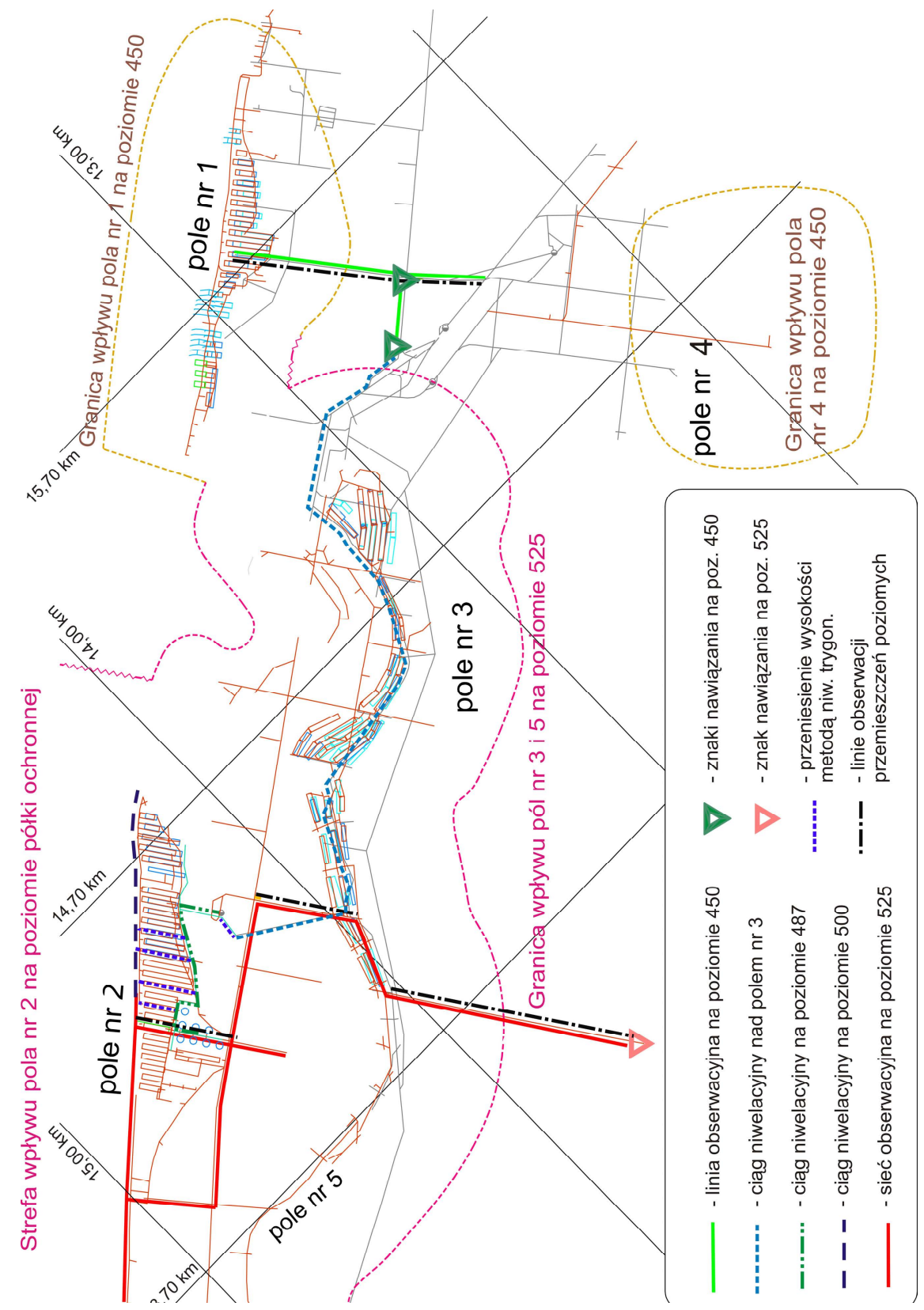

Rys. 3. Schemat lokalizacji pól eksploatacyjnych oraz projekt linii pomiarowych

Fig. 3. Scheme of location of exploitation fields and design of measuring lines 
w 1962 roku, głównie na liczącej kilkadziesiąt znaków sieci na poziomie 450 nad polem $\mathrm{nr} 1$ oraz na krótszych ciągach niwelacyjnych na pozostałych poziomach. Obserwacje były jednak prowadzone nieregularnie; ujawniły się też problemy z trwałością znaków i sposobem stabilizacji. Stosunkowo najlepiej rozpoznane jest zjawisko naturalnego zaciskania pustek poeksploatacyjnych (dzięki systematycznym, trwającym przeszło 30 lat pomiarom wykonywanym przez OBR Chemkop [3]). Należy jednak nadmienić, że badania konwergencji dotyczą jedynie wybranych pionów w każdym z pól eksploatacji, a nie strefy pod półka ochronną. Aby ustalić wymaganą dokładność, a także częstotliwość pomiarów sieci, przeanalizowano dane pochodzące $\mathrm{z}$ powyższych źródeł oraz uwzględniono najnowsze, interesujące wyniki obserwacji linii pomiarowej nad polem $\mathrm{nr}$ 1, pochodzące z kilku ostatnich lat. Wyniki tych pomiarów pozwalają jednak na przybliżone określenie ruchów pionowych wnętrza górotworu:

- przemieszczenia pionowe w rejonie centrum niecki: około $-3 \mathrm{~mm} / \mathrm{rok}$,

- przemieszczenia poziome w rejonie centrum niecki: około $-5 \mathrm{~mm} / \mathrm{rok}$,

- przemieszczenia poziome nad krawędzią eksploatacji pola: około $+6 \mathrm{~mm} / \mathrm{rok}$,

- przemieszczenia poziome na granicy i poza granicą oddziaływania eksploatacji: około $\pm 2 \mathrm{~mm} /$ rok.

Powyższe dane pozwalają oszacować wielkość spodziewanych deformacji oraz określić sposób obserwacji przemieszczeń znaków i baz w sieci. Ułatwiają również dobór odpowiedniego sprzętu pomiarowego z uwzględnieniem jego parametrów dokładnościowych oraz możliwości pracy w trudnych warunkach kopalnianych. Pokazane wartości osiadań są wielkościami znaczącymi, możliwymi do wyznaczenia metodą niwelacji technicznej (przy zastosowaniu odpowiedniego cyklu obserwacyjnego).

\section{Założenie kompleksowej sieci kontrolnej}

Sieć kontrolna zakładana w Kopalni Soli „Kłodawa” ma służyć do obserwacji deformacji stropowej półki ochronnej nad filarowo - komorowym górotworem. Większość znaków została zastabilizowana nad polem 2 (Rys. 3), gdyż tam zgromadzona jest zdecydowana większość objętości pustek kopalnianych, które są źródłem deformacji rozwijających się w otoczeniu pola i propagujących ku powierzchni terenu poprzez caliznę półki ochronnej.

Przed rozpoczęciem prac projektowych, a także w trakcie ich trwania, dokonywano systematycznego przeglądu wyrobisk, aby sprawdzić możliwość instalacji znaków oraz ocenić występujące utrudnienia odnośnie ich stabilizacji bądź wykonania pomiaru. Sytuacja taka miała miejsce na odcinku pomiędzy parą komór cylindrycznych a komorami prostopadłościennymi (nad centralnym rejonem pola numer 2), gdzie stwierdzono zasypanie urobkiem fragmentu przekopu (Rys. 4). Ze względu na przewidywane duże deformacje tego rejonu wyrobiska zdecydowano się na poszerzenie prześwitu przy stropie chodnika do około 1,5 metra. Rysunek 5 przedstawia przykład stabilizacji znaku spągowego, zabezpieczanego przykrywką z tworzywa sztucznego. 


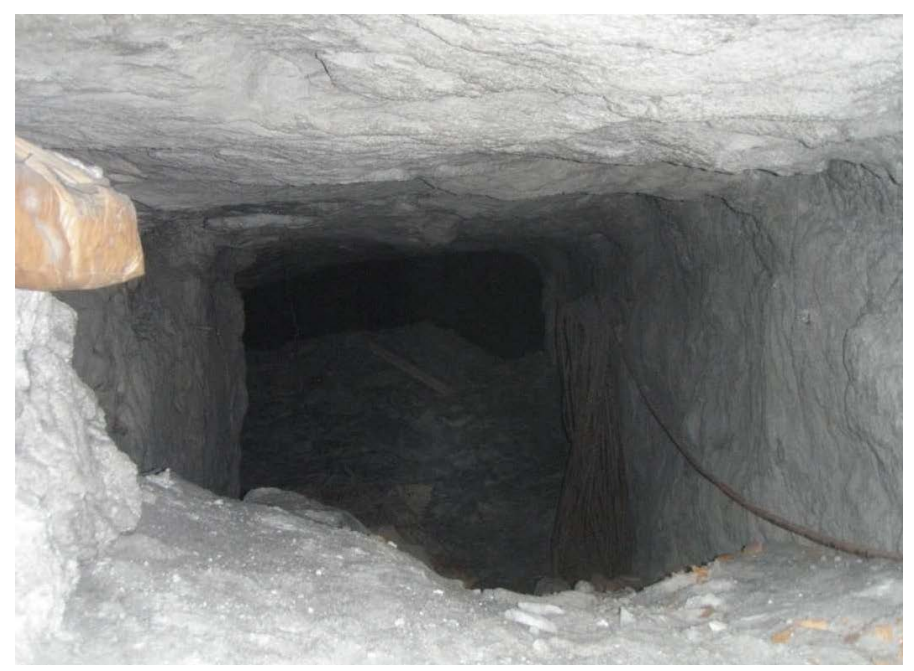

Rys. 4. Zasypany fragment przekopu

Fig. 4. An overwhelmed part of the excavation

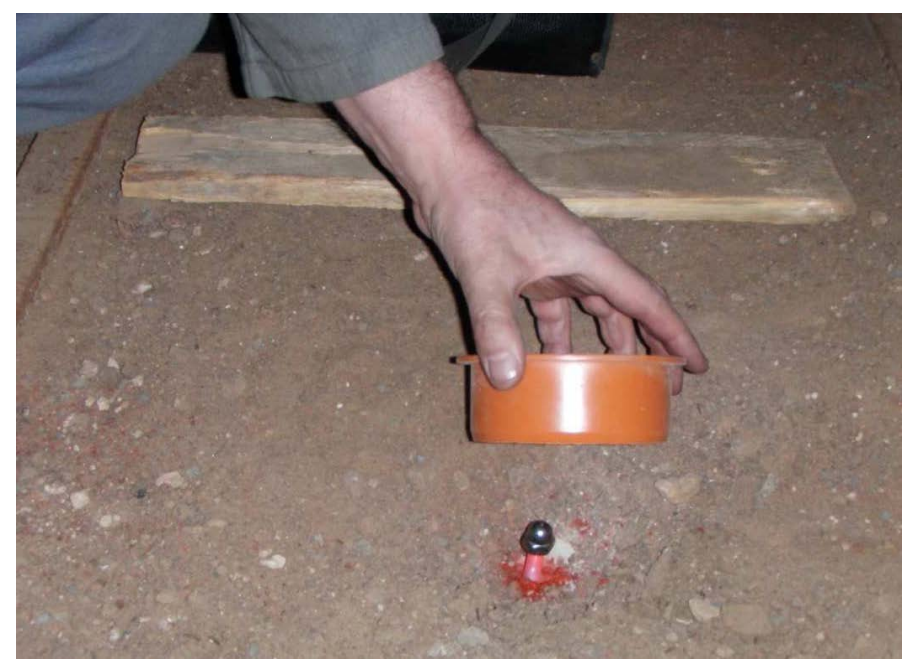

Rys. 5. Spągowy znak pomiarowy z osłoną

Fig. 5. Floor measuring sign with cover

Segment niwelacyjno-dtugościowy sieci kontrolnej

W okresie od listopada 2013 do marca 2014 roku została wykonana instalacja znaków sieci i uzupełniające rozpoznanie wyrobisk dla realizacji opisywanego projektu. Wcześniejsze projekty stabilizacji z lat 2009/2010 zostały częściowo zmienione i zmodyfikowane, a część punktów sieci została wykorzystana i włączona do bieżących ciągów. 
Otwory dla stabilizacji znaków o głębokościach od 0,3-0,7 m wykonywano w caliznach po usunięciu luźnych warstw na spągu. Pręty stalowe mocowano w otworach przy pomocy mikro-ładunków klejowych. Na końcówce pręta wprowadzonego do wyrobiska mocowany był właściwy znak pomiarowy $\mathrm{w}$ formie nierdzewnej nakrętki kołpakowej. Na znakach spągowych przewidzianych do pomiarów długości, nawiercono wcześniej otworki o średnicy $1 \mathrm{~mm}$ (centr znaku). Wszystkie znaki spągowe zostały ponadto zabezpieczone za pomocą przykrywki z grubego tworzywa i przysypanie urobkiem - Rys. 5. Są one zupełnie niewidoczne w wyrobisku, co zabezpiecza je przed uszkodzeniem przez osoby postronne; odsłaniane są tylko na czas wykonywania pomiaru.

Segment konwergencyjny sieci kontrolnej

Instalacja pionowych baz konwergencyjnych przeprowadzona została pod koniec marca 2014 roku w wyrobiskach komorowych, położonych bezpośrednio pod ochronną półką stropową Kopalni Soli „Kłodawa” w polu numer 2. Znak spągowy $\mathrm{w}$ formie mosiężnego trzpienia osadzano przez wklejenie w otworze, wykonanym w litej caliźnie solnej w rejonie geometrycznego środka komory (Rys. 6). Na stropie komory, ponad znakiem spągowym, mocowano specjalną tarczę sygnalizacyjną (Rys. 7). Bazy te zostały dostosowane do planowanego sposobu ich pomiaru - za pomocą dalmierza laserowego Disto. W trakcie przeprowadzanych prac napotkano na szereg trudności, gdyż znaczna liczba komór okazała się niedostępna (brak wejścia), bądź też warunki górnicze (stan wyrobiska) uniemożliwiały jej wykorzystanie do celów pomiarowych. Plan pomiaru przewiduje również zaniwelowanie znaków spągowych baz konwergencyjnych w nawiąza-

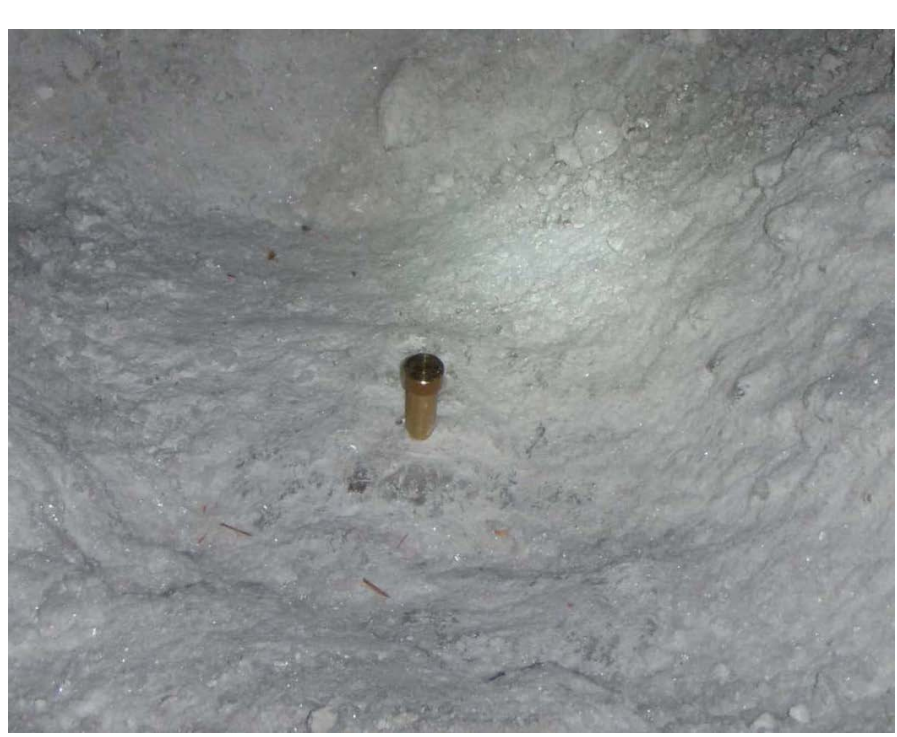
niu do najbliższego reperu w chodniku przyfilarowym. Ma to na celu między innymi określenie względnych przemieszczeń tych dwóch znaków w dłuższej perspektywie czasowej.

Rys. 6. Spągowy punkt bazy konwergencyjnej

Fig. 6. Floor point of convergence base 


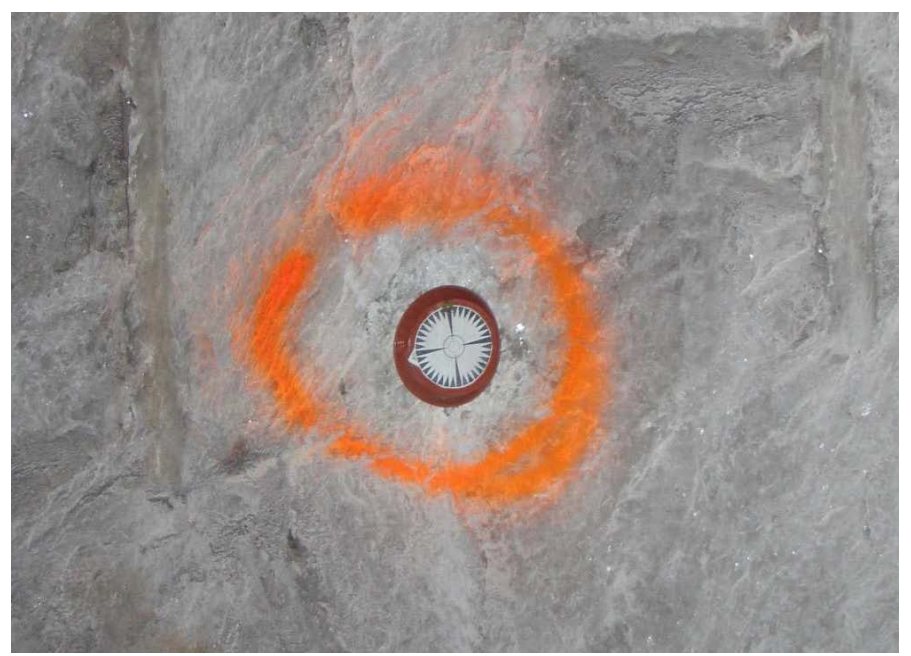

Rys. 7. Tarcza sygnalizacyjna zamocowana na caliźnie solnej

Fig. 7. Signal target mounted on salt rock

Założona sieć pomiarowa służy do obserwacji przemieszczeń pionowych, poziomych i konwergencji w wyrobiskach pod stropową półką ochronną - nad polami nr 2 i 3 (największe pustki poeksploatacyjne), a także nr 1 i częściowo $\mathrm{nr}$ 5. Punkty sieci pomiarowej stanowią narzędzie monitoringu deformacji w strefie górotworu kluczowej dla bezpieczeństwa kopalni. Kompleksowa sieć obserwacyjna liczy 46 znaków zainstalowanych w wyrobiskach chodnikowych na poziomach 450, 487, 500 i 525 (zob. Rys. 3). Uzupełnieniem sieci jest 17 baz pomiaru konwergencji pionowej, założonych w komorach najwyższych poziomów 475 , 500, 525 i 550. Segment niwelacyjny sieci (łączna długość ciągów ponad $8 \mathrm{~km}$ ), nawiązany jest $\mathrm{w}$ układzie lokalnym do wgłębnych znaków nawiązania $\mathrm{w}$ wyrobiskach kopalni, położonych poza zasięgiem przewidywanych oddziaływań poeksploatacyjnych (na poziomach 450 i 525). Segment pomiarów długościowych (dla określenia przemieszczeń poziomych) stanowi 14 boków linii obserwacyjnych o łącznej długości ponad $2 \mathrm{~km}$, prostopadłych do rozciągłości pól eksploatacji nr 1, 2, 3 i 5. Do nowopowstałej sieci włączono również szereg znaków już istniejących i wykorzystywanych we wcześniejszych pomiarach.

W ujęciu liczbowym charakterystykę założonej, kompleksowej sieci obserwacyjnej przedstawia tabela 1 .

Pomiar niwelacyjny typowego znaku podwójnego, polegający na określeniu wysokości głowicy stropowej i spągowej, pozwoli na obliczenie średniej wysokości umownego znaku wirtualnego. Wyliczona wysokość tego znaku posiada tę właściwość, że nie będzie obarczona ruchem pionowym lokalnych calizn, przy założeniu w miarę jednakowego wpływu obniżania stropu i wypiętrzania spągu. Założenie takie jest tym bardziej uzasadnione, że większość punktów obserwacyjnych sieci zlokalizowana jest w najstarszej, przystropowej części kopalni - w wyrobiskach kilkudziesięcioletnich, które przeszły już fazę intensywnej konwergencji. 
Tabela 1. Charakterystyka sieci obserwacyjnej w Kopalni Soli "Kłodawa"

Table 1. Characteristics of the observation network in the Kłodawa Salt Mine

\begin{tabular}{|l|c|c|}
\hline \multicolumn{1}{|c|}{ Cecha charakterystyczna sieci } & Nowo zalożone & Istniejące \\
\hline Liczba podwójnych znaków niwelacyjnych & 38 & 8 \\
\hline Długość ciągów niwelacji geometrycznej & $7400 \mathrm{~m}$ & $900 \mathrm{~m}$ \\
\hline Liczba boków pomiaru długości & 9 & 5 \\
\hline Długość linii obserwacji przemieszczeń poziomych & $1500 \mathrm{~m}$ & $700 \mathrm{~m}$ \\
\hline Liczba odcinków niwelacji trygonometrycznej & 5 & - \\
\hline Liczba baz pomiaru konwergencji & 9 & 8 \\
\hline
\end{tabular}

\section{Pomiary wysokościowe}

\section{Pomiar metoda niwelacji geometrycznej}

Pomiary niwelacyjne wykonywano w Kopalni Soli „Kłodawa” w dniach od 7 lipca do 14 września 2014 roku. Do pomiarów użyto niwelator South DL - 202, składanych łat kodowych z libelą oraz klasycznej żabki niwelacyjnej. Przed przystąpieniem do zasadniczej niwelacji punktów sieci dokonano kilku próbnych pomiarów na odcinkach testowych, aby przyjąć optymalne długości celowych oraz sposób oświetlania łat. Zaznaczyć należy, że wszystkie pomiary prowadzone były w nieczynnych wyrobiskach górniczych kopalni, a więc pozbawionych zupełnie oświetlenia. Jedynym źródłem światła była typowa lampa górnicza, służąca do oświetlenia łaty $\mathrm{i}$ instrumentu. Po kilku wspomnianych pomiarach próbnych przyjęto zasadę, że długość celowej nie może przekraczać 40 metrów. Optymalne (i najczęściej stosowane) były celowe o długości około 35 metrów - nie spowalniały one pomiaru i pozwalały na zachowanie odpowiednich dokładności.

W trakcie prac pomiarowych niwelator ustawiony był na najwyższą możliwą precyzję odczytu $(0,1 \mathrm{~mm})$. Wykorzystano także funkcję uśredniania odczytów wielokrotnych (optymalnie ustawiono 4 odczyty). Właściwy pomiar rozpoczęto na odcinku pomiędzy wgłębnymi znakami nawiązania o numerach 45000 i 45001 na poziomie 450, których regularne obserwacje prowadzone są od 2006 roku. Uzyskano potwierdzenie ich wzajemnej stabilności, gdyż na przestrzeni blisko 8 lat, różnica ich wysokości zmieniała się w przedziale od 0 do $2,5 \mathrm{~mm}$. Jako główny znak nawiązania sieci na poziomie 450 przyjęto reper $\mathrm{nr} 45000$ - jest to punkt o głębokim posadowieniu (podobnie jak repery 45001 i 52550). Głębokość osadzenia takiego znaku (w litej caliźnie solnej) wynosi ok. $3 \mathrm{~m}$, co ma na celu niezawodne jego zespolenie $\mathrm{z}$ górotworem i uniknięcie zwiększonych przemieszczeń warstw bliskich konturowi wyrobiska. Wszystkie odcinki (na każdym z poziomów kopalni) zostały pomierzone metodą podwójnej niwelacji geometrycznej ze środka. Dla odcinków, na których uzyskana różnica przewyższeń z dwóch pomiarów była zbyt duża, wykonano trzeci pomiar kontrolny, tak aby zminimalizować ryzyko wystąpienia błędów. Sumaryczna długość ciągów niwelacji na poziomach 450, 
487, 500 i 525 wyniosła $7980 \mathrm{~m}$. Długość najkrótszego ciągu między wgłębnymi znakami nawiązania na poziomach 450 i 525 wynosi 5100 metrów. Przykładowe schematy pomiaru wraz z wynikami pokazano na rysunku 8 . Na szkicach podano dla poszczególnych odcinków niwelacyjnych różnice wysokości (w [mm]) w kierunku głównym i powrotnym (np. $>79>$; $<81<$ ). Rozbieżności nie są duże $(0-4 \mathrm{~mm})$, nawet przy dużych przewyższeniach (np. na odcinku 50030 - 48722, Rys. 8a), co daje podstawę do pozytywnej oceny zastosowanej procedury pomiaru.
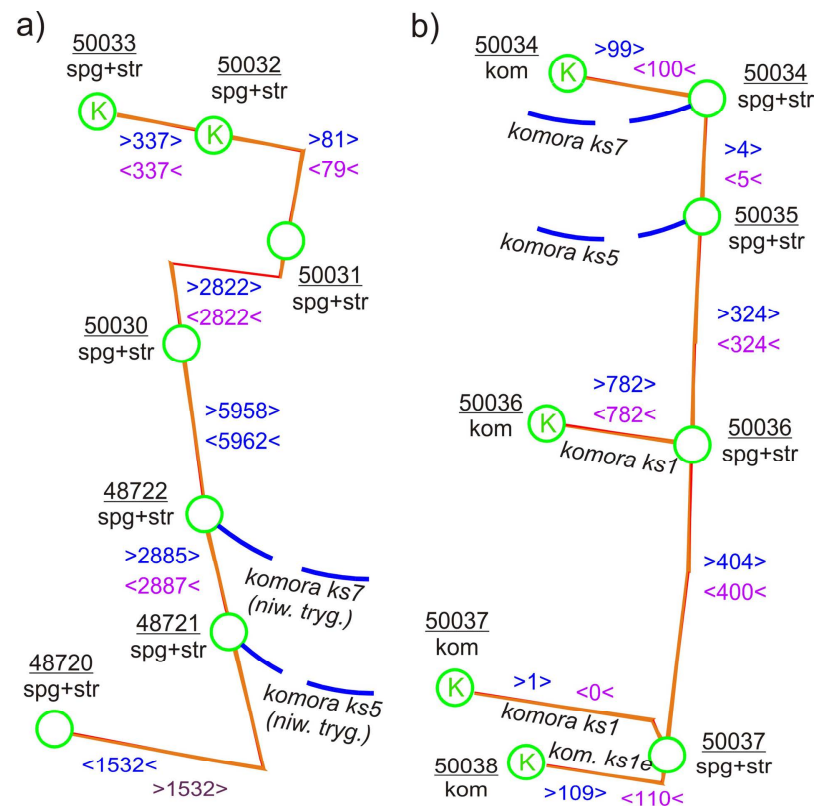

Rys. 8. Przykładowy szkic i wyniki pomiaru metodą niwelacji geometrycznej: a) na poziomie 487 ; b) na poziomie 500 (różnice wysokości podano $\mathrm{w}[\mathrm{mm}]$ )

Fig. 8. Sample sketch and the results of measurement by direct leveling: a) at level 487; B) at level 500 (height differences are given in $[\mathrm{mm}]$ )

\section{Pomiar metoda niwelacji trygonometrycznej}

$\mathrm{W}$ trakcie prac pomiarowych prowadzonych w kopalni w Kłodawie niwelacja trygonometryczna była jedyną możliwą metodą wyznaczenia różnic wysokości na kilku najtrudniejszych odcinkach. Pochylnie oraz komory solne to miejsca, gdzie klasyczna niwelacja geometryczna praktycznie była niewykonalna (przejścia między-poziomowe) lub bardzo utrudniona (średni kąt nachylenia pochylni: ok. $30^{\circ}$ ). Przejścia z ciągiem wysokościowym przez komory i pochylnie wykonywane były w celu połączenia czterech niezależnych poziomów kopalni, czyli uzyskania kompleksowego zasięgu mierzonej sieci (Rys. 9, 10). Do prac pomiarowych wykorzystano tachimetr Elta R55, tarczę celowniczą umieszczaną na statywie oraz ruletkę. 
Na każdym z odcinków pomiar wykonywany był metodą ze środka, z trzech niezależnych stanowisk instrumentu. Pomiar przewyższeń odbywał się kilkukrotnie, w dwóch położeniach lunety. Dzięki temu uzyskano znaczną ilość niezależnych obserwacji, pozwalającą na wewnętrzną kontrolę dokładności pomiaru. Tarczę celowniczą ustawiano nad punktem sieci na statywie ze spodarką (centrowanie, poziomowanie) oraz domierzano wysokościowo. Łącznie pomiar tą metodą wykonano na pięciu przęsłach o długościach od 75 do $145 \mathrm{~m}$ i deniwelacjach od 8 do $38 \mathrm{~m}$.

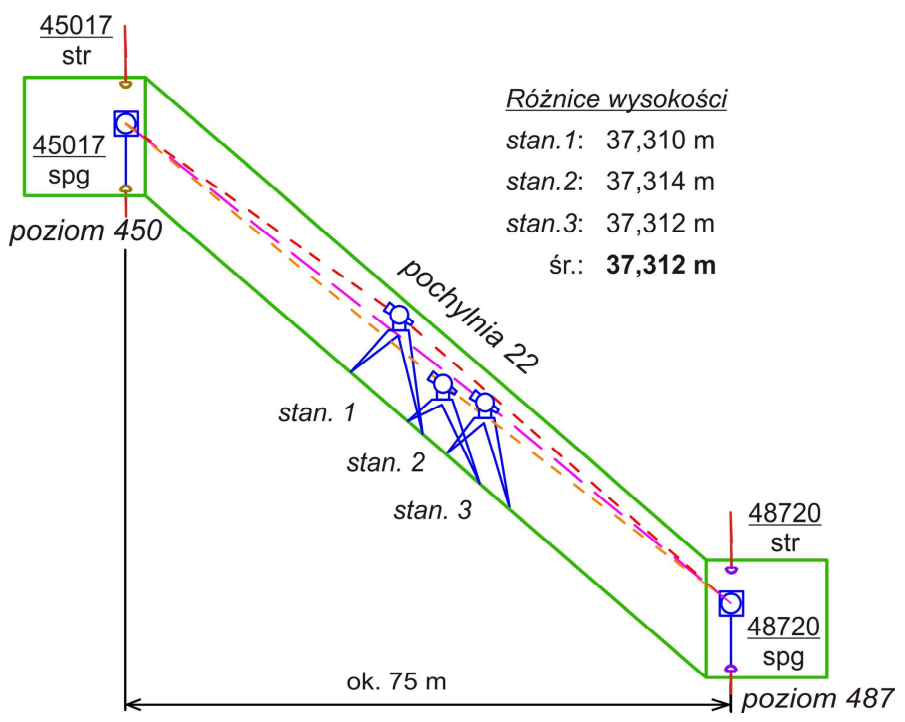

Rys. 9. Szkic i wyniki pomiaru metodą niwelacji trygonometrycznej w pochylni $\mathrm{nr} 22$

Fig. 9. Sketch and measurement results by trigonometric leveling in the ramp No 22

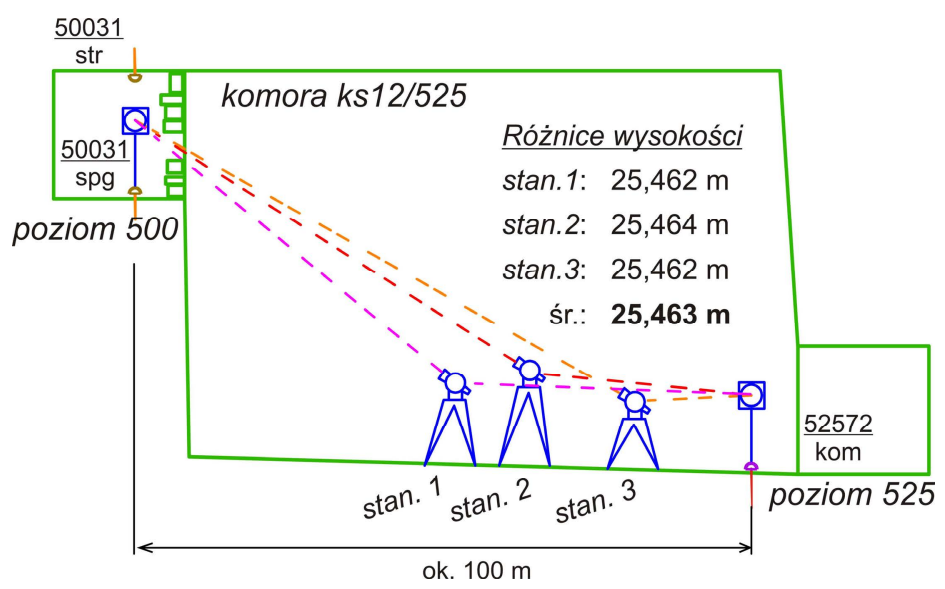

Rys. 10. Szkic i wyniki trygonometrycznego przeniesienia wysokości w komorze ks12/525

Fig. 10. Sketch and results of trigonometric transfer of height in the cave ks 12 / 525 
Rozbieżność uzyskanych wyników kilkukrotnego wyznaczenia różnicy wysokości metodą niwelacji trygonometrycznej (Rys. 9, 10) wynosi zaledwie od 0 do $4 \mathrm{~mm}$, co przy przewyższeniach rzędu 30 metrów jest zadowalającym efektem zastosowania tej metody pomiaru wysokościowego w pochylniach i komorach poeksploatacyjnych.

$\mathrm{Na}$ rysunku 11 pokazano zamknięcia oczek wysokościowych, złożonych z odcinków niwelacji geometrycznej oraz trygonometrycznej. Minimalne odchyłki zamknięcia $(1 \div 2 \mathrm{~mm})$ w oczkach, w których wykonywano przeniesienia wysokości, świadczą o staranności pomiaru i wewnętrznej spójności dokładnościowej sieci - pomimo stosowania dwóch różnych technik pomiaru niwelacyjnego.

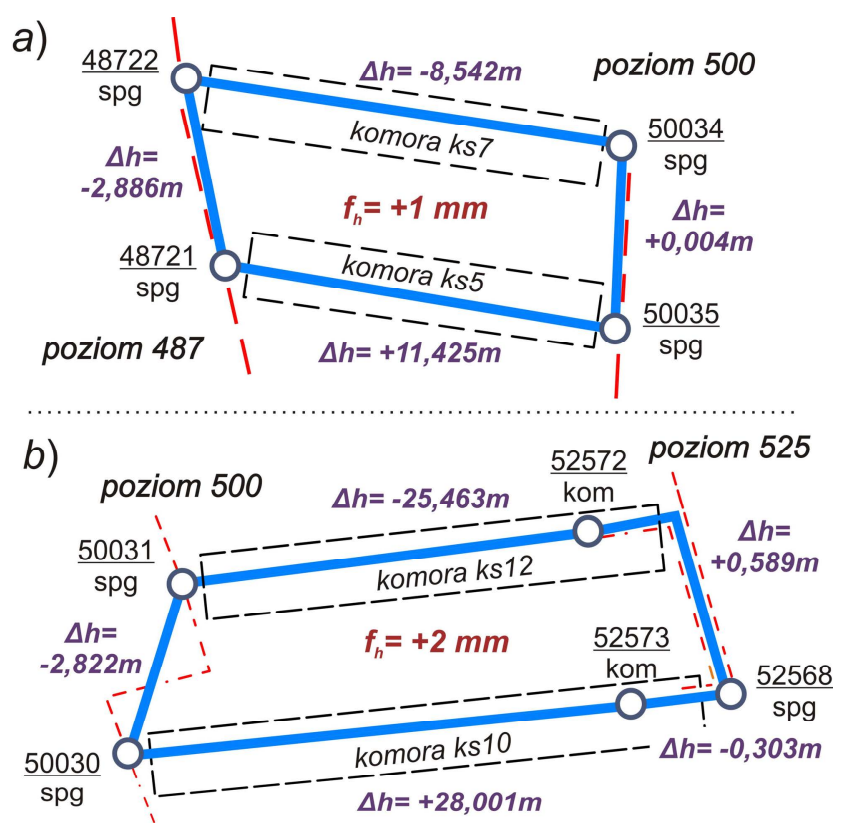

Rys. 11. Odchyłki zamknięcia oczek w miejscach przeniesienia wysokości (przykłady a, b)

Fig. 11. Deviations of leveling mesh closure at height transfer locations (examples a, b)

\section{Pomiar konwergencji wyrobisk oraz długości baz poziomych}

Pomiar konwergencji wyrobisk prowadzony był od lipca do września 2014 roku przy wykorzystaniu dalmierza Disto-D5. Dodatkowo znaki spągowe baz konwergencyjnych na poziomach 500 i 525 zostały zaniwelowane do najbliższego reperu (w chodniku przyfilarowym). Do segmentu konwergencyjnego sieci włączono trzy istniejące już bazy w komorach ks $1 \mathrm{~d} / 500$, ks1e/500 i ks11/525. Łącznie pomiarem objęto 10 baz w 9 komorach leżących bezpośrednio pod stropową półką ochronną pola numer 2 (Rys. 3). Dodać należy, że dalmierz Disto-D5 był wyposażony podczas prac pomiarowych w specjalny uchwyt (Rys. 12), umożliwiający 
jego precyzyjne mocowanie na spagowym punkcie pomiarowym oraz dokładne celowanie na tarczę umieszczoną w stropie komory. Dalmierz jest w tym przypadku zamocowany nieruchomo - podobnie jak instrument geodezyjny na statywie.

Poza długimi bazami (w komorach solnych) mierzonymi dalmierzem Disto, do baz konwergencyjnych zaliczyć można również podwójne znaki niwelacyjne (spąg - strop) w wyrobiskach chodnikowych. Zastosowana konstrukcja podwójnego znaku sieci niwelacyjnej pozwoli w kolejnych cyklach pomiarowych na wyznaczenie zaciskania pionowego chodników w miejscu stabilizacji znaków i określenie ewentualnych poprawek do rzędnej wysokościowej uzyskanej z niwelacji. Średnie długości chodnikowych baz pionowych wyznaczono na podstawie wielokrotnych obserwacji niwelacyjnych.

Pomiar długości boków osnowy (dla celów badania przemieszczeń poziomych) wykonany został przy użyciu tachimetru Elta R55, tarczy celowniczej mocowanej na statywie oraz pionu optycznego PZO. Pion wykorzystywany był w przypadkach pomiaru odległości poziomych pomiędzy punktami stropowymi sieci. Należało wtedy przy pomocy pionu zrzutować punkt stropowy na spąg i nad tak wyznaczonym punktem ustawić instrument bądź tarczę celowniczą (Rys. 13). Pomiar długości baz poziomych prowadzony był na poziomie 525 . Każdy odcinek mierzony był dwukrotnie $\mathrm{z}$ obu końców przy niezależnym centrowaniu, po 3 odczyty odległości poziomej w każdym z dwóch położeń lunety. Pomierzono ogółem 9 odcinków bazowych (zob. Rys. 3) o długościach od 102 do 214 m i łącznej długości ponad $1500 \mathrm{~m}$.



Rys. 12. Dalmierz Disto-D5 w uchwycie zamocowany na znaku pomiarowym

Fig. 12. Disto-D5 in the holder mounted on the measurement mark

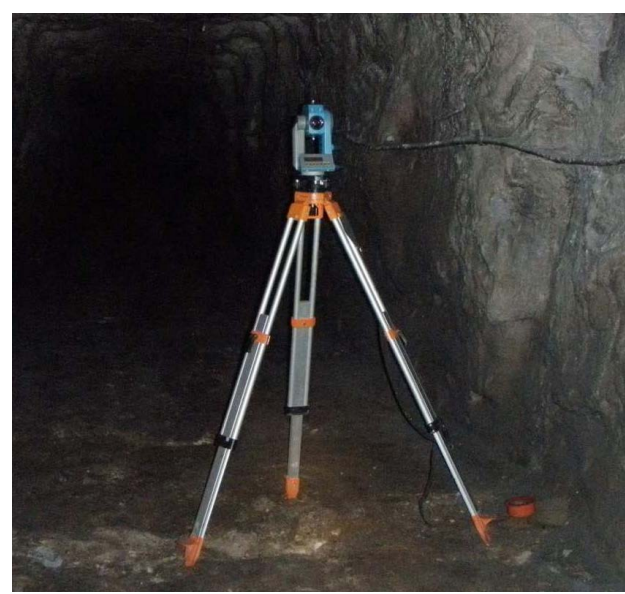

Rys. 13. Pomiar długości bazy tachimetrem

Fig. 13. Length measurement of the base line using a tachymeter 


\section{Analiza wyników pomiaru wysokościowego}

Wielopoziomowy segment niwelacyjny sieci nawiązany jest w układzie lokalnym do dwóch wgłębnych znaków wysokościowych w wyrobiskach kopalni, położonych poza zasięgiem przewidywanych oddziaływań poeksploatacyjnych, na poziomach 450 i 525 (zob. Rys. 3). Różnica wysokości między tymi znakami nie była dotychczas znana; została określona dopiero w trakcie obecnego, pierwszego pomiaru. Zatem, do obliczenia wysokości znaków sieci w układzie lokalnym nie zastosowano procedury wyrównania ścisłego obserwacji, a jedynie wyznaczono poprawki wynikające z zamknięcia oczek niwelacyjnych. Odchyłkę zamknięcia dużego oczka niwelacyjnego na poziomie 525 rozrzucono proporcjonalnie do liczby stanowisk na poszczególnych odcinkach. Natomiast odchyłki w oczkach między-poziomowych przypisano odcinkom niwelacji trygonometrycznej (ze względu na oczywistą, niższą dokładność tej metody) (por. Rys. 11).

Po rozrzuceniu odchyłek w oczkach niwelacyjnych obliczono wysokości znaków spągowych sieci w lokalnym układzie odniesienia, przyjmując dla znaku nawiązania 45000 wysokość umowną $H_{45000}=1000,000 \mathrm{~m}$. Podczas kolejnych cykli pomiarów okresowych sieci niwelacyjnej kluczowe znaczenie (przy interpretacji wyników) będzie miała stałość przyjętych znaków nawiązania na poziomach 450 (znak 45000) i 525 (znak 52550). Łączący je ciąg niwelacyjny o długości ok. 5,1 km mierzony był metodą niwelacji geometrycznej (w zdecydowanej przewadze) i uzupełniony dwoma odcinkami między-poziomowej niwelacji trygonometrycznej. Aby określić dokładność wyznaczenia różnicy wysokości $(\Delta h)$ między znakami nawiązania, wykorzystano wzór wynikający z prawa przenoszenia się błędów średnich [1]:

$$
m_{\Delta h}=\sqrt{m_{\text {geom }}^{2}+m_{\text {tryg }}^{2}}
$$

gdzie: $\quad m_{\Delta h}$ - średni błąd wyznaczonej różnicy wysokości między znakami 45000 i 52550 ;

$m_{\text {geom }}, m_{\text {tryg }}$ - średnie błędy składowych z niwelacji geometrycznej i trygonometrycznej (odpowiednio).

Dokładność pomiaru odcinka metodą niwelacji geometrycznej określono w następujący sposób:

$$
m_{\text {geom }}=\sqrt{n \cdot\left(m_{w}^{2}+m_{p}^{2}\right)}=13,4 m m
$$

gdzie: $\quad m_{w}, m_{p}$ - średnie błędy odczytu ,wstecz” i „,w przód” (przyjęto: $m_{w}=m_{p}=$ $1 \mathrm{~mm}$ ); $n$-ilość stanowisk niwelatora w odcinku (przyjęto: $n=90$ ).

Dla dwóch odcinków między-poziomowych (pochylnia i komora), mierzonych metodą niwelacji trygonometrycznej, zastosowano wzór (por. [13]): 


$$
m_{\text {tryg }}=\sqrt{m_{s}^{2}+D^{2} \cdot\left(\frac{m_{z}}{\rho^{c c}}\right)^{2} \cdot \cos ^{2} z+m_{D}^{2} \cdot \operatorname{tg}^{2} z}
$$

gdzie: $m_{s}$-średni błąd wysokości sygnału (lustra; przyjęto: $2 \mathrm{~mm}$ );

$m_{z}$ - średni błąd pomiaru kąta pionowego $z$ (przyjęto: $15^{\mathrm{cc}}$ );

$m_{D}$ - średni błąd pomiaru odległości zredukowanej $D$ (przyjęto: $5 \mathrm{~mm}$ );

$\rho^{c c}$ - przelicznik pomiędzy miarą gradową a łukową kąta.

Wykorzystując rzeczywiste danych pomiarowe z pochylni 22 (tryg1) i komory ks10/525 (tryg2) obliczono błędy średnie pomiaru różnicy wysokości na tych odcinkach - odpowiednio, według wzoru (3):

- $m_{\text {tryg } 1}=5,2 \mathrm{~mm}$;

- $m_{\text {trrgg } 2}=4,2 \mathrm{~mm}$.

Uwzględniając te wartości oraz wcześniej obliczony błąd niwelacji geometrycznej (2), uzyskano ostatecznie informację o dokładności wyznaczonej różnicy wysokości między znakami 45000 i 52550 - zgodnie z (1):

- $m_{\Delta h} \approx 15 \mathrm{~mm}$.

Wyliczona wartość błędu średniego wynika ze specyficznej, przestrzennej struktury sieci oraz zastosowanych metod pomiarowych (długość ciągu niwelacyjnego wynosi ponad $5 \mathrm{~km}$, a różnica wysokości ok. $75 \mathrm{~m}$ ). W kontekście funkcjonowania sieci jako narzędzia monitoringu deformacji poeksploatacyjnych, błąd ten może stanowić jeden ze wskaźników pozwalających określić stopień zaufania do rejestrowanych w przyszłości przemieszczeń pionowych.

\section{Podsumowanie i wnioski}

Przedmiotem niniejszej pracy była metodyka pomiaru specjalistycznej, wielosegmentowej sieci obserwacyjnej, pozwalającej na monitorowanie poeksploatacyjnych deformacji górotworu w rejonie stropowej półki ochronnej nad wyrobiskami Kopalni Soli „Kłodawa”. Rozległa sieć punktów obserwacyjnych obejmuje fragment górotworu pomiędzy poziomami 450 a 525 i pozwala rejestrować następujące przejawy jego deformacji:

- przemieszczenia pionowe pochodzące od pól eksploatacji nr 1, 2, 3 i częściowo 5,

- przemieszczenia poziome na liniach pomiarowych prostopadłych do rozciągłości pól nr 1, 2 i 3 ,

- zaciskanie pionowe wybranych komór pól nr 1 i 2 położonych bezpośrednio pod półką ochronną,

- zaciskanie pionowe chodników pól nr 1, 2 i 3 w strefie stropu eksploatacji.

Lokalne nawiązanie niwelacyjne sieci do znaków dołowych, położonych poza zasięgiem spodziewanych wpływów eksploatacyjnych, pozwala uniknąć pracochłonnego i kosztownego dowiązania do stałych znaków na powierzchni. Powtórne pomiary wykonane na istniejącym od 2006 roku fragmencie sieci na poziomie 
450 nad polem nr 1 dowiodły słuszności tej tezy. Wgłębne znaki nawiązania o numerach 45000 i 45001 zachowują stabilność i będą mogły być wykorzystywane jako znaki nawiązania w przypadku kolejnej serii pomiarowej. Zastosowanie w konstrukcji sieci podwójnych znaków (spągowy oraz stropowy), lokalizowanych w środku przekroju chodnika, pozwala zminimalizować niedogodności pomiarowe i obliczeniowe, wynikające z procesu zaciskania chodnika. Linia obserwacji przemieszczeń poziomych została zlokalizowana nad centrum pola $\mathrm{nr} 2$ i przedłużona poza pola $\mathrm{nr} 3$ i 5, co pozwoli wyznaczyć wielkość tych przemieszczeń w newralgicznym rejonie centrum deformacji. Uzupełnieniem obserwacji zmian poeksploatacyjnych w skali globalnej całej kopalni (pól eksploatacyjnych) są lokalne pomiary konwergencji pionowej komór położonych bezpośrednio pod calizną półki ochronnej.

Zastosowane techniki pomiarów klasycznych są wystarczające do określenia ruchu przestrzennego punktu sieci z dokładnością na poziomie kilku do kilkunastu milimetrów, co przy odpowiednio dobranym interwale obserwacyjnym pozwoli na monitorowanie deformacji tej calizny ochronnej. Ustalenie poprawnego interwału obserwacyjnego wymaga wykonania kolejnego cyklu pomiarowego pełnej sieci po ok. 2 - 3 latach. Pozwoli to na określenie rzeczywistych wielkości przemieszczeń pionowych i poziomych, charakterystycznych dla przystropowej partii górotworu (obecnie słabo rozpoznanych).

Warunkiem skutecznego funkcjonowania założonej sieci obserwacyjnej jako narzędzia kontroli zjawisk deformacyjnych w strefie pod półką ochronną jest prowadzenie systematycznych, cyklicznych obserwacji w dłuższym okresie czasu. Wymaga to ochrony znaków sieci przed uszkodzeniem lub zniszczeniem oraz zapewnienia bezpiecznego dostępu do wyrobisk na czas wykonywania pomiarów.

\section{Literatura}

[1] Baran L.W.: Teoretyczne podstawy opracowania wyników pomiarów geodezyjnych, PWN, Warszawa 1999.

[2] Bieniasz M.: Wykorzystanie współczesnych technik pomiarów geodezyjnych do wyznaczenia deformacji górotworu na przykładzie Kopalni soli „Kłodawa”. Praca magisterska, Uniwersytet Rolniczy w Krakowie, 2015.

[3] Bieniasz J., Wojnar W.: Analiza porównawcza deformacji poeksploatacyjnych kłodawskiego systemu komorowo - filarowego przy pionowym i ukośnym układzie wyrobisk, OBR GS „CHEMKOP”, Kraków 2008.

[4] Borecki M., Chudek M.: Mechanika górotworu, Wydawnictwo „Śląsk”, Katowice 1972.

[5] Budryk W.: Zapadliska na terenie miasta Inowrocławia, Przegląd Górniczo - Hutniczy, Sosnowiec, nr 8, 1933, s. 431-444.

[6] Kortas G. (red.): Ruch górotworu w rejonie wysadów solnych. Wydawnictwo Instytutu Gospodarki Surowcami Mineralnymi i Energią, PAN, Kraków 2008.

[7] Ney R., Ślizowski K.: Kopalnia „Solno” poligonem doświadczalnym w skali cechsztyńskiego Zagłębia solnego Europy Wschodniej. Gospodarka Surowcami Mineralnymi, Kraków, t. 7, z. 4, 1991, s. 957-979. 
[8] Maj A.: Opracowanie modelu konwergencji wyrobisk w podziemnych kopalniach soli. Rozprawa doktorska. AGH Kraków 2009.

[9] Pietruszka K.: Prognozowanie deformacji na terenach górniczych metodą badań modelowych (MES) weryfikowanych pomiarami geodezyjnymi, Warsztaty z cyklu ,Zagrożenia naturalne w górnictwie", PAN, Mat. Symp. 2002, s. 285-292.

[10] Rozporządzenie Ministra Środowiska z dnia 22 grudnia 2011 r. w sprawie dokumentacji mierniczo - geologicznej, Dz. U. 2011, nr 291, poz. 1713.

[11] Szpetkowski S.: Pomiary deformacji na terenach górniczych, Wydawnictwo „Śląsk”, Katowice 1978.

[12] Ustawa z dnia 9 czerwca 2011 r. - Prawo geologiczne i górnicze; Dz. U. 2011, nr 163, poz. 981.

[13] Wytyczne techniczne G-4.3: Bezpośrednie pomiary wysokościowe. Główny Urząd Geodezji i Kartografii, Warszawa 1981.

[14] www.poznajpolske.onet.pl/ (dostęp: 21.08.2017).

[15] www.chemkop.pl/ (dostęp: 21.08.2017).

[16] www.sol-klodawa.com.pl/ (dostęp: 21.08.2017).

[17] www.cluktur.pl/ (dostęp: 21.08.2017).

\section{EVALUATION OF THE POSSIBILITY OF USING GEODETIC MEASUREMENT TECHNIQUES TO DETERMINE THE DEFORMATION OF THE ROCK MASS IN THE KLODAWA SALT MINE}

\section{S u m m a r y}

One of the aspects of the salt mine's functioning is the subsidence of the surface of the terrain and the part of the rock mass that is above the excavations. This process should be continuously monitored, i.a. by geodetic measurements. The aim of the paper is to show the possibility of using geodetic techniques to investigate the phenomenon of rock mass deformation in the area of exploitation of rock salt in the Kłodawa Salt Mine. The first stage of the work was the marking of the multifunctional observation network in excavations of the highest levels of the mine. Then the network was measured using several geodetic survey techniques. The final result of the work is the analysis of received measurement results in relation to archival data. The results of this analysis are to be used to determine the direction of actions aimed at ensuring the continued, safe and efficient exploitation of the Kłodawa salt dome.

Keywords: displacement, convergence, marking of benchmarks, leveling

Przestano do redakcji: 19.09.2017 r.

Przyjęto do druku: 15.12.2017 r. 